\title{
International technology spillovers, human capital and productivity linkages: evidence from the industrial sector
}

\author{
Nicholas Apergis · Claire Economidou • \\ Ioannis Filippidis
}

(C) The Author(s) 2009. This article is published with open access at Springerlink.com

\begin{abstract}
The paper estimates an empirical model that is consistent with a variety of Research and Development (R\&D)-driven models of growth where technology is transmitted via trade to other industries, both domestically and internationally, by being embodied in differentiated intermediate goods. The evidence is based on data from 21 manufacturing industries in six European Union countries for the period 1980-1997. The contribution of the paper lies in showing how by including human capital in the model and employing suitable econometric procedures the magnitude of R\&D spillovers reported in the existing literature can be affected, while pointing to a major role of human capital in economic growth process.
\end{abstract}

Keywords Total factor productivity - Technology spillovers · Human capital · R\&D $\cdot$ Panel cointegration · Manufacturing industries

JEL classification $\mathrm{C} 23 \cdot \mathrm{F} 1 \cdot \mathrm{L} 6 \cdot \mathrm{O} 33$

\section{Introduction}

Recent theories of innovation-driven growth models have stressed the importance of innovation efforts-domestic or foreign-as key propagator of economic

\footnotetext{
N. Apergis

Banking and Financial Management, University of Piraeus, 18534 Piraeus, Greece

C. Economidou $(\bowtie)$

Utrecht School of Economics, Utrecht University, Utrecht 3512 BL, The Netherlands

e-mail: C.Economidou@econ.uu.nl

I. Filippidis

Aristotle University of Thessaloniki, School of Economics, 54124 Thessaloniki, Greece
} 
growth. ${ }^{1}$ The seminal work of Coe and Helpman (1995) and a number of subsequent studies explore empirically the contribution of research and development (R\&D) spillovers to country's total factor productivity (TFP) level. ${ }^{2}$ A smaller body of empirical work examines the same issue at the industry level. Some studies focus on the international intra-industry R\&D spillovers (Frantzen 2000; Scarpetta and Tressel 2002; Griffith et al. 2004; Cameron et al. 2005; Apergis et al. 2008), while, more recently, a growing body explores the simultaneous impact of international intra-industry and inter-industry R\&D spillovers (Fagerberg and Verspagen 1999; Keller 2002; Frantzen 2002; Badinger and Egger 2008) on industry's TFP level. Overall, the empirical evidence provides support for the beneficial effects of R\&D spillovers on industry's (country's) productivity performance and the importance of trade in their propagation.

A shortcoming, however, of the innovation-driven growth models is that they do not adequately consider the role of human capital. The theoretical literature stresses that, like in the case of $R \& D$, human capital enhances the ability of the workforce to learn, absorb and work with new technologies created by innovation efforts, and therefore, facilitates the realization of R\&D spillovers (Redding 1996). Further, human capital accounts for aspects of innovation not captured by the R\&D sector, i.e., 'learning-by-doing' or 'on the job training' (Romer 1990).

Attempts to include a human capital variable in innovation-driven growth models are made by Benhabib and Spiegel (1994), Engelbrecht (1997), del Barrio-Castro et al. (2002) and Frantzen (2000), who examine the impact of international R\&D spillovers and human capital on countries' TFP level. These studies conclude that omission of human capital results in overestimating the size of R\&D coefficients; however, there seems to be no consistency as to the way that human capital affects TFP. ${ }^{3}$ More recently, a handful of studies investigate the effect of international intra-industry R\&D spillovers and human capital on industry's productivity performance (e.g., Frantzen 2000; Griffith et al. 2004; Cameron et al. 2005;

\footnotetext{
1 See Rivera-Batiz and Romer (1991) and Grossman and Helpman (1991).

2 A voluminous stream of research has investigated the various types and channels of national and international technology spillovers and their impact on country's (industry's) productivity growth. A line of research has focused on the embodied knowledge spillovers. Prominent examples are the works of Coe and Helpman (1995), Coe et al. (1997), Engelbrecht (1997), Lichtenberg and van Pottelsberghe. (1998), Kao et al. (1999), Frantzen (2000, 2002), van Pottelsberghe and Lichtenberg (2001), Park (2004), Luintel and Khan (2004) and Falvey et al. (2004). The main channel of technology spillovers in all aforementioned studies is imports of intermediate goods (machinery and equipment). The study of Falvey et al. (2004) further investigates the role of exports as an additional channel. A relative smaller number of studies assess the relevant importance of disembodied knowledge spillovers to embodied technology transfer. The studies of Fagerberg and Verspagen (1999) and Lee (2006) examine these types of technology spillovers at disaggregated and aggregated level, respectively. The list of studies reported here is by no means exhaustive.

3 These studies build on Coe and Helpman's (1995) model specification, which is extended to include human capital. For instance, Engelbrecht $(1997,2002)$ finds the impact of the level of human capital to be economically and statistically significant. Further, as in Benhabib and Spiegel (1994), he argues that human capital should not be modeled like other inputs. Its impact is significant on country's TFP through its interaction with a productivity catch up variable, pointing at a major role of human capital in absorbing foreign technology. The growth rate and level of human capital, as well as its interaction with the catch up process, are shown in Frantzen (2000) to significantly affect TFP growth. Finally, the study of del BarrioCastro et al. (2002) points to a superior role of the level of human capital in TFP gains.
} 
Apergis et al. 2008). Although these attempts are an important step to disentangle the effects of innovation spillovers and human capital at disaggregate (industry-) level, they offer mixed results as to the role of human capital, and further ignore an important dimension of innovation spillovers, that of the inter-industry.

Consequently, the aim of this paper is to assess empirically the linkages between international trade-related R\&D spillovers, human capital and productivity. To our knowledge, no study has attempted so far to investigate these linkages performing an intra- and inter-industry analysis.

The paper makes two contributions to the existing literature: First, it shows how the inclusion of human capital affects the results reported in the past related literature. A handful of studies have examined the linkages of international intraand inter-industry spillovers and TFP growth, namely Fagerberg and Verspagen (1999), Keller (2002), Frantzen (2002) and Badinger and Egger (2008). We extent an R\&D-driven model of growth, similar to that used in the aforementioned studies, to allow for human capital. To enhance the robustness of our results and avoid contradictionary findings reported in the literature on the relationship between human capital and TFP (Engelbrecht 1997, 2002; Frantzen 2000; del Barrio-Castro et al. 2002; Griffith et al. 2004; Cameron et al. 2005), two sets of human capital estimates are used. Human capital estimates from the Barro and Lee (1993, 1996, 2001) database, which is commonly used in the literature, and estimates from the de la Fuente and Domènech (2006) database, which contains more reliable data from all existing human capital databases. ${ }^{4}$ Ideally, we should use human capital data at the industry level. However, this is not an option since there is no reliable measure of human capital at the industry level.

Second, the paper employs a more suitable econometric estimation procedure to account for shortcomings of estimation approaches used in the relevant literature. For instance, ignoring the non-stationary nature of the data and making use of OLS, as it is often the practice in the past literature (Keller 2002), one can obtain highly unreliable standard errors, ill-suited for statistical inference. To avoid such problems, this study considers the application of panel-based unit root tests and cointegration analysis. Using dynamic panel-based cointegration techniques, we avoid spurious regression problems due to I(1) nature of the variables and exploit the long-run information of the data in an efficient manner. ${ }^{5}$ The cointegrating vectors are then estimated using the fully modified ordinary least squares (FMOLS) estimator, which accounts for the integration and cointegration properties of the data and allows for consistent and efficient estimators of the long-run relationship.

Panel cointegration techniques are particularly well suited for this study for a number of reasons. One is the focus on the long-run relationship of technology

\footnotetext{
${ }^{4}$ De la Fuente and Domènech (2006) construct a revised version of the Barro and Lee (1996) data set for a sample of OECD countries using previously unexploited sources, correcting for measurement errors and removing sharp breaks in the data that reflect changes in classification criteria. It is shown that these revised data perform much better than past human capital databases in a number of growth specifications. For a discussion, see de la Fuente and Domènech (2006).

${ }^{5}$ Exploiting both cross-section and time-series dimension of the data, panel-based cointegration methods avoid well-known problems that occur in using traditional time series cointegration testing, i.e., lower power of statistics due to small sample sizes.
} 
spillovers, human capital and TFP growth, which would be obscured if, for example, the equation was estimated on first differences rather than on the levels of variables. A second is the increased power that comes from exploiting commonalities across countries and industries, given the limited number of time-series observations. A third important reason is that, under cointegration, parameter estimates are super consistent, and hence robust to problems such as omitted variables, simultaneity, and endogeneity. Thus, using panel cointegration techniques to estimate the long-run effect of domestic and foreign R\&D and human capital on TFP overcomes the endogeneity problem, thereby avoiding the difficult task of finding valid instruments, for instance, for R\&D capital, which would be necessary if the focus was on the short-run relationship.

Our work is not the only one that relies on panel-based cointegration analysis to assess the long run linkages of innovation (captured by R\&D stocks) and productivity. Recently, a growing number of studies (Lichtenberg and van pottelsberghe de la Potterie 1998; Kao et al. 1999; Funk 2001; Frantzen 2002; Guellec et al. 2004; Lee 2006), use dynamic panel-based cointegration techniques to study R\&D spillovers and their impact on aggregate (country-level) and disaggregate (industry-level) productivity growth (see Coe et al. 2008 for excellent survey). These studies typically find that TFP is cointegrated with domestic and foreign R\&D capital, although the latter was often defined in alternative ways. To our knowledge, no study so far provides disaggregated panel data estimates based on panel integration and cointegration methods in employing an R\&D-driven model of growth extended to account for human capital.

On the modeling front, we follow Keller's (2002) approach, where the long-run growth of an industry is endogenously driven by R\&D investments. Through trade, many industries domestically and internationally can benefit from the designs by purchasing new intermediate goods from different R\&D-conducting sources. The latter, captures the notion of technology spillovers in the framework. The model distinguishes four different sources of technology transmission: R\&D conducted in the domestic industry itself, $R \& D$ contacted in other domestic industries, R\&D contacted in the same industry abroad, and R\&D contacted in other industries abroad.

Keller (2002) empirically implements his model for thirteen manufacturing industries, in eight countries over the period 1970-1991. Overall, the results support the existence of positive and statistically significant technology spillovers, both domestically and internationally. The average contribution of the former substantially exceeds that of the latter, whereas the influence of other industries' R\&D is somewhat weaker than that of own industry R\&D.

Keller's (2002) model is extended here to include human capital. Our empirical analysis is based on a sample that consists of manufacturing industries that are twice as disaggregated as those used in Keller (2002) while the time span is extended to cover recent developments in the industrial sector. Our results reveal that by including human capital in the analysis the magnitude of R\&D spillovers becomes smaller compared to those reported in Keller (2002); however, they remain statistically significant. Finally, human capital is found to be statistically and quantitatively significant, corroborating that both R\&D and human capital need to be included in growth empirics. 
The rest of the paper is organized as follows: Sect. 2 briefly describe the model specification and data. The econometric methodology and results are reported in Sect. 3. Section 4 concludes.

\section{Model specification and data}

We follow Keller's (2002) modeling approach. The empirical specification employed here is a version of equation (11) in Keller (2002, p. 9), extended to include human capital ${ }^{6}$ :

$$
\begin{aligned}
\log F_{i j, t}= & \log A_{i j}+\beta_{1} \log S_{i j, t}+\beta_{2} \log S_{i j, t}^{\mathrm{io}}+\beta_{3} \log S_{i j, t}^{f}+\beta_{4} \log S_{i j, t}^{f, \text { io }} \\
& +\beta_{5} \log \mathrm{HC}_{i, t}+\varepsilon_{i j, t}
\end{aligned}
$$

where subscript $i$ refers to the country, $j$ to the industry and $t$ to time; $F_{i j, t}$ is the total factor productivity; $A_{i j}$ is the country-industry fixed effect; $S_{i j, t}, S_{i j, t}^{\mathrm{io}}, S_{i j, t}^{f}, S_{i j, t}^{f, \text { io }}$ denote respectively the R\&D stocks of the domestic own-industry, ${ }^{7}$ domestic otherindustry (input-output weighted sum of cumulative R\&D stocks of all other domestic industries), foreign own-industry (bilateral import-share weighted foreign R\&D stock), and foreign other-industry (input-output coefficients and intermediate import shares weighted sum of cumulative R\&D stocks of all other foreign industries); and $\varepsilon_{i j}$ is i.i.d. error term.

One of the contributions of the present paper is that it examines domestic and international intra-and inter-industry spillovers taking also into consideration the role of human capital. The modeling of human capital, however, in growth regressions has been controversial. Within the endogenous growth theory, three channels (and accordingly modeling approaches) have been put forward.

The first channel relates to 'Lucas' approach (Aghion and Howitt 1998), based on Lucas (1988), assumes that growth is driven by the accumulation of human capital. Human capital may contribute to growth in a way analogous to any other factor of production, such as the amount of labor or physical capital. More particularly, human capital may act as an engine to attract other factors of production. The quality of labor, captured by the level of education and skills, attracts capital stock (Lucas 1990) increasing thus the possibilities for further growth. This view is also shared in the neo-classical growth models. ${ }^{8}$

\footnotetext{
6 The technology transmission in Keller's (2002) model specification (equation 11) is modeled in two ways: through goods trade, based on input-output tables ('I/O specification'), and through technology flow matrix ('TM specification'). Keller argues that the I/O specification performs much better than the TM specification. Here, we also model the technology transmission using the I/O specification.

7 The terms "own-industry" and "intra-industry" have the same meaning and, therefore, used interchangeably throughout the paper.

${ }^{8}$ For instance, Mankiw et al. (1992), who build on Solow neo-classical model, advocate such an approach on both theoretical and empirical grounds, and obtain a better fit after including human capital in the analysis. They offer empirical evidence to confirm its positive contribution to growth, reconciling the empirical evidence with the theoretical prediction of the neo-classical model. Barro and Sala-i-Martin (1995) argue from a similar perspective.
} 
The second channel postulates that the level of human capital determines the capacity of nations to innovate new technologies suited to domestic production and to imitate existed advanced foreign technologies (Romer 1990).

Closely related to the previous view, the 'Nelson and Phelps' approach (Aghion and Howitt 1998) argues that human capital affects a country's ability to innovate and catch-up with more advanced technologies. Greater endowment of human capital increases, ceteris paribus, the rate of technical change by encouraging both innovation and diffusion of technology (Nelson and Phelps 1966).

The latter view seemed to have been confirmed by the study of Benhabib and Spiegel (1994), which develops a 'hybrid' model to assess the relationship between growth and human capital. Their approach is founded on Nelson and Phelps (1966) model, which by including human capital in levels (the innovative component) and human capital levels interacted with a technology gap component was preferred and confirmed a positive role for human capital in growth.

However, Temple (1999) has shown that the presence of outliers can be held responsible for lack of positive and statistical significant estimates in Nelson and Phelps (1966) study. Once outliers are deleted, human capital (in level) becomes positive and statistically significant in a standard production function, supporting the Lucas approach. Reverse causation (simultaneity) between growth and human capital could be another reason of lack of robust findings. Moreover, there is evidence that when (the level of) human capital is considered alongside separate R\&D capital stock variables, both types of variables, which capture the level of innovation (human capital captures also other 'learning' effects), become statistically significant and have the expected sign. A further interesting explanation for lack of convincing evidence has been put forward in de la Fuente and Domènech (2000). They conclude that the Benhabib and Speigel (1994) and other related studies (e.g., Islam 1995; Pritchett 1996) results are generated by poor quality data, namely from the use of the Barro and Lee (2000) and World Bank datasets.

Overall, on empirical grounds, there is little agreement in the literature as to the appropriate treatment of human capital. As Engelbrecht (2003) argues in his empirical attempt to clarify the 'correct' approach in modeling human capital, when robust estimation methods are applied (correcting for outliers) then both approaches, i.e. Lucas vis-à-vis Nelson-Phelps, find empirical support. However, simultaneity and data quality issues still need to be addressed.

Following the theoretical arguments in the literature, we allow human capital to affect growth via the first of the aforementioned channels. Human capital, proxied by years of schooling embodied in workforce, captures the ability of the labor to innovate and make the best use of the imported technology. ${ }^{9}$

\footnotetext{
9 We use the level of human capital and not the growth rate of human capital, as other studies (Engelbrecht 2003) also take into consideration. Our estimation technique relies on panel integration and cointegration analysis where there variables enter in levels in order to assess the long-run nature of their relationship.
} 
Applying an appropriate estimation technique, discussed in the next section, we avoid the well-known problems of simultaneity. ${ }^{10}$ Further, we consider quality data on human capital to avoid measurement issues. Two sets of human capital estimates are used. Human capital estimates from the Barro and Lee (1993, 1996, 2001) database, which is commonly used in the literature and estimates from the de la Fuente and Domènech (2006) database, which contains more reliable data from all existing human capital databases. The latter database is a revised version of the Barro and Lee (1996) data set for a sample of OECD countries using previously unexploited sources, correcting for measurement errors and removing sharp breaks in the data that reflect changes in classification criteria. It is shown that these revised data perform much better than past human capital databases in a number of growth specifications (de la Fuente and Domènech 2006). Finally, we check for suspicious values (outliers) that could influence our results (Temple 1999).

Our analysis covers 21 two-, three-and four-digit industries in manufacturing sector for six European Union (EU) countries (Finland, France, Germany, Italy, Netherlands, Spain). The time period investigated covers from 1980 to 1997 - the longest time period for which all variables are available for the widest selection of industries. The manufacturing industries and their International System of Industries Classification (ISIC, revision 3 ) code are provided in Table 2 in the Appendix. TFP series and all types of R\&D stock $\left(S_{i j}, S_{i j}^{\text {io }}, S_{i j}^{f}, S_{i j}^{f, i o}\right)$ are constructed as in Keller (2002). See Appendix1 for details. The same International System of Industries Classification (ISIC) code was used in all data sources. All price figures are expressed in euros at 1995 purchasing power parity (PPP). Country-level human capital estimates are extracted from Barro and Lee $(1993,1996,2001)$ and de la Fuente and Domènech (2006).

Data sources as well as descriptive statistics of the variables are provided in Appendix 1. Table 3 reports basic statistics of TFP, R\&D stocks and industries' value-added shares to manufacturing. The statistics report mean and standard deviation of the variables over the sample period. As Table 3 shows, there is considerable heterogeneity as to the productivity performance of various industries as well as to the domestic and imported innovation efforts. Table 4 reports basic statistics for human capital retrieved from Barro and Lee $(1993,1996,2001)$ and de la Fuente and Domènech (2006) databases. The statistics report mean and standard deviation of the variables over the sample period. We observe significant differences among the two databases, both in magnitude of the human capital estimates and the variation for the majority of the countries in our sample. Finally, we test for outliers. We find no evidence of influential ones.

\footnotetext{
${ }^{10}$ Note that our variables have the same dimensions except for human capital. All R\&D stock variables in our analysis are provided at the industry level while human capital at the country level. Different dimensions in variables could be problematic in the estimation process if eventually the dimensions collapse. For instance, assume $n$ industries $t$ periods and $c$ countries. If, by chance $c=n$ then it is impossible to estimate the regression coefficients. Therefore, different dimensions of variables in a regression have nothing to do with the biasness of the estimated coefficients but rather with one not being able to estimate it. However, this is certainly not the case in our study.
} 


\section{Econometric methodology and results}

Our purpose is to estimate Eq. (1) using panel-based integration and cointegration techniques. However, for comparison purposes, we first report in Table 1, column (1), Keller's (2002) estimates. Then, we replicate his analysis for our sample. Next, we add human capital. First, the Barro and Lee human capital estimates and then the de la Fuente and Domènech. Finally, we re-estimate the preferred specification using panel-based cointegration estimation techniques.

We begin our analysis by estimating Eq. (1) without human capital for our own data sample, and using, as in Keller (2002), the ordinary least squares (OLS) estimation procedure. Column (2) in Table 1 displays the results. We find positive and statistically significant $R \& D$ spillovers, the size of which is not very different from that reported in Keller. The main difference lies in the magnitude of the inter-industry R\&D spillovers, which in our case are quantitatively larger than those displayed in column (1). This is not surprising since Keller's sample consists of 13 industries (against 21 in our case) that are, on average, about twice as aggregated as ours.

Next, we re-estimate specification (2) controlling this time for human capital. Column (3) reports the OLS estimates based on the Barro and Lee human capital measure $\left(\mathrm{HC}^{\mathrm{BL}}\right)$, while column (4) contains the OLS estimates based on the de la Fuente and Domènech measure $\left(\mathrm{HC}^{\mathrm{DD}}\right)$. The results again indicate that there

Table 1 Panel estimates (dependent variable is $F_{i j, t}$ )

\begin{tabular}{llllll}
\hline & $(1)$ & $(2)$ & $(3)$ & $(4)$ & $(5)$ \\
& OLS & & & FMOLS \\
\hline$S_{i j, t}$ & $0.607(0.119)$ & $0.547[3.78]^{* *}$ & $0.380[2.11]^{* *}$ & $0.342[5.19]^{* *}$ & $0.359[3.49]^{* * *}$ \\
$S_{i j, t}^{\mathrm{io}}$ & $0.571(0.558)^{\dagger}$ & $0.631[3.76]^{*}$ & $0.362[4.24]^{*}$ & $0.357[5.00]^{* *}$ & $0.391[4.71]^{* * *}$ \\
$S_{\mathrm{ij,t}}^{\mathrm{f}}$ & $0.092(0.091)^{*}$ & $0.101[2.04]^{*}$ & $0.112[2.21]^{*}$ & $0.172[4.34]^{*}$ & $0.191[3.82]^{* * *}$ \\
$S_{i j, t}^{f, \text { io }}$ & $0.294(0.078)$ & $0.306[2.98]^{*}$ & $0.114[2.44]^{* *}$ & $0.117[4.74]^{*}$ & $0.129[4.38]^{* * *}$ \\
$\mathrm{HC}_{i, t}^{\mathrm{BL}}$ & & & $0.040[2.18]^{*}$ & & \\
$\mathrm{HC}_{i, t}^{\mathrm{DD}}$ & & & & $0.568[5.69]^{*}$ & $0.340[16.48]^{* * *}$ \\
\hline
\end{tabular}

For brevity, country-industry specific intercept terms are not presented. OLS and FMOLS stand for ordinary least squares and fully-modified ordinary least squares, respectively. $F_{i j t}$ is the total factor productivity (TFP) for a given industry $j$ in country $i$ at time $t$, and $S_{i j, t}, S_{i j, t}^{\mathrm{io}}, S_{i j, t,}^{f} S_{i j, t}^{f \text { io }}$ denote the domestic own-industry, domestic other-industry, foreign own-industry, foreign other-industry R\&D stock, respectively. $\mathrm{HC}_{i, t}^{\mathrm{BL}}$ is the Barro and Lee human capital measure while $\mathrm{HC}_{i, t}^{\mathrm{DD}}$ is the de la Fuente and Domènech human capital measure. All variables are expressed in logarithms

Column (1) reports Keller's specification (T6.4), Table 6, Keller (2002, p. 15). Standard errors in the parentheses. $(\dagger)$ Coefficient is smaller than one at $8 \%$ significance level. ( $\dagger$ ) Coefficient is larger than zero at a $5 \%$ significance level

Column (2) reproduces Keller's OLS estimates to facilitate comparisons

Columns (3) and (4) present the OLS estimates of our model (Eq. 1)

Column (5) displays the FMOLS estimates of the preferred specification (column 4)

$*, * *, * * *$ Significant at 10,5 and $1 \%$, respectively; $t$-ratios in square brackets 
are positive and statistically significant international intra-industry and interindustry technology spillovers. However, these spillovers are quantitatively smaller compared to those reported in column (2) and Keller's findings, column (1). The results underline that omission of human capital leads to overestimated R\&D coefficients (Redding 1996; Engelbrecht 1997; del Barrio-Castro et al. 2002).

In addition, the estimated elasticity of total factor productivity $(F)$ with respect to the de la Fuente and Domènech human capital measure is larger compared to that of the Barro and Lee. The latter, appears to be quantitatively and statistically much weaker compared to the de la Fuente and Domènech estimate. As it has been argued in the literature, weak (or lack of) relationship between human capital and productivity might be due to poor data quality (de la Fuente and Domènech 2006). Controlling for the quality of human capital data by employing the de la Fuente and Domènech measure, the size and statistical significance of the human capital estimate in the model improves significantly.

However, there are some concerns with the OLS estimation procedure. Although the OLS estimates of variables that have stochastic trends converge fast to their true parameter values, in other words they are 'super consistent' (Stock 1987), their distribution is non-standard. This is due to finite sample bias caused by the endogeneity (reverse causality) of the regressors and serial correlation in the error term. ${ }^{8}$ As a result, the parameter estimates may be imprecise and their standard errors could lead to misleading statistical inference. Chen et al. (1999) have shown that that the bias-corrected OLS estimator does not improve over the OLS in general. Their results suggested that alternatives, such as fully modified OLS (FMOLS) estimator or dynamic OLS (DOLS) estimator might be more promising in cointegrated panel regressions (Baltagi 2005).

Accordingly, we rely on these techniques in estimating the panel regression. In particular, we apply FMOLS estimator for dynamic and heterogeneous panels, ${ }^{11}$ proposed by Pedroni (2000), which addresses the problem of non-stationarity as well as controls for serial correlation and potential endogeneity of the regressors as the latter are determined endogenously in non-stationary processes. ${ }^{12}$ The FMOLS estimates are shown to follow an asymptotic normal distribution and their standard errors allow the valid calculation of $t$-tests. ${ }^{13} \mathrm{We}$ estimate the (preferred) specification in column (4) using FMOLS estimator.

\footnotetext{
11 The main underlying reasons regarding the heterogeneity in our panel lie in the differences across industries (technology they employ and their policies regarding R\&D) and countries (institutions, e.g., educational systems).

12 An alternative estimation technique is the dynamic ordinary least squares (DOLS) estimator, developed by Kao and Chiang (2000). It is virtually equivalent and, in our case, provides similar results, which are available upon request.

13 Keller (2002) also stresses that the consistency of the OLS estimates can be harmed in presence of simultaneity and omitted variable bias. He advocates the use of instrumental variable (IV) estimation procedure but due to lack of good instruments, he relies on OLS estimates from various specifications.
} 
Before embarking, however, on the FMOLS estimation procedure, we have first to confirm that the data are indeed non-stationary. The null hypothesis of nonstationarity is tested using the panel unit root test of Im et al. (2003), which allows each member of the cross-section to have different autoregressive root and autocorrelation structures under the alternative hypothesis. All variables are tested in both levels and first differences. Results are reported in Table 5 in the Appendix. Panel unit root tests support the hypothesis of a unit root in all variables as well as the hypothesis of zero integration in first differences. These findings allow testing for cointegration among the variables in consideration.

We use the Pedroni (1999) framework to test for cointegration. Based on cointegration residuals, Pedroni develops seven different panel cointegration statistics for the null hypothesis of no cointegration by allowing for heterogeneous fixed effects, determinist trends and heterogeneous short-run dynamics. Pedroni cointegration results are reported in Table 6 in the Appendix. The calculated test statistics reject the null hypothesis of no cointegration among variables and the hypothesis of one cointegrating vector is accepted.

Having established that the variables are structurally related, the long-run equation is estimated using the FMOLS estimator (Pedroni 2000). Panel FMOLS estimates of the cointegrating relationship are reported in Table 1, column (5). The results indicate the existence of a unique long-run equilibrium relationship among TFP level, R\&D stocks and human capital. The parameter estimates by OLS (column 4) and by FMOLS (column 5) are found to be quite close. This implies that the potential endogeneity bias in the former, caused by feedback effects and/or by shocks affecting the variables, is rather modest. The serial correlation robust $t$-values of the FMOLS are lower, as expected, than that of the corresponding $t$-values of the OLS estimates.

As in Keller (2002), the average influence of domestic R\&D spillovers (0.75) is found to be much stronger than that of foreign (0.32) while the influence of other industries' R\&D (0.52) is found somewhat weaker than that of own industry R\&D effect (0.55). However, the inclusion of human capital in our analysis has reduced the size of the estimated R\&D coefficients compared to those found in Keller (2002). As it has been argued (Romer 1990; Redding 1996; Engelbrecht 1997), human capital accounts for aspects of innovation not captured by the R\&D sector, i.e., 'learning-by-doing' or 'on the job training' and further enhances the ability of the workforce to learn, absorb and work with new technologies created by innovation efforts. Not properly accounting for human capital in a regression equation could result in overestimating the impact of R\&D. This finding is in line with studies that support omission of human capital leads to biased (overestimated) R\&D coefficients (Engelbrecht 1997; del BarrioCastro et al. 2002).

Further, the estimated long-run elasticity of TFP to human capital is much larger compared to previous studies (Engelbrecht 1997; Frantzen 2000) and closer to the microeconomic literature on private returns from schooling (Ashenfelter et al. 1999) and to the literature that uses the de la Fuente and Domènech (2006) human capital database (Bassanini and Scarpetta 2001; del Barrio-Castro et al. 2002). Finally, our 
estimates are robust to alternative model specifications and have been found stable over the period of investigation. ${ }^{14}$

\section{Conclusion}

One of the main challenges in policy agendas, and in particular in Lisbon's agenda for the EU, is to raise productivity. That means better exploitation of new technologies that already exist, but also increasing the rate of technological innovation. A question of interest in this respect is to what extent productivity could benefit from these two sources of growth namely, technological innovation and technology spillovers across national borders.

The present study estimates an empirical model that is consistent with a variety of R\&D-driven model of growth where technology is developed in an industry via R\&D effort and transmitted through trade to other industries, both domestically and internationally, by being embodied in differentiated intermediate goods.

The analysis is based on data from two-to four-digit manufacturing industries in six EU countries over the period 1980-1997. Our analysis improves on earlier comparable studies (Keller 2002), which concentrated on the relation between productivity and international inter-industry and intra-industry R\&D spillovers, by (1) accounting for the role of human capital, and (2) employing more suitable econometric estimation technique.

Our results are easy to summarize. We confirm the existence of a unique long-run equilibrium relationship among trade-related R\&D spillovers, human capital and productivity. In addition, the role of trade as vehicle of technology transfer is also confirmed. Further, both domestic and foreign R\&D spillovers, which are intra- and inter-industry in nature, are found to have positive and statistically significant impact on industry's productivity performance. The average influence of domestic $R \& D$ is found to be stronger than that of foreign $R \& D$, while the contribution of intra-industry R\&D spillovers slightly exceeds that of inter-industry spillovers. The support of significant inter-industry spillover effects, however, strongly highlights that findings of past studies (Scarpetta and Tressel 2002; Griffith et al. 2004; Cameron et al. 2005; Apergis et al. 2008), which account for international (intraindustry) technology spillovers relying on technological leader-follower approaches, rule out an important transmission mechanism of technology spillover, that of the inter-industry channel.

\footnotetext{
${ }^{14}$ We have examined a number of variants of our model specification. For instance, we have extended our specification to allow for some interaction terms, i.e., human capital interacted with each one of the four R\&D stocks or just with the domestic R\&D stocks. In all cases, our original results remained unaltered. The interaction terms have found to be positive (quantitatively, the terms $\mathrm{HC} \times S_{\mathrm{ij}, \mathrm{t}}$ and $\mathrm{HC} \times S_{\mathrm{ij}, \mathrm{t}}^{\mathrm{f}}$ are the largest) but statistically insignificant. Finally, we have also examined for sub-sample stability of the parameters. In the context of panel-based cointegration, we apply an LM-based test, developed by Westerlund (2006), for the null hypothesis of cointegration that allows for the possibility of multiple structural breaks in both the level and trend of a cointegrated panel regression. The test also allows for endogenous regressors, serial correlation and an unknown number of breaks that may be located at different dates for different individuals. The test fails to reject a stable long-run relationship between R\&D stocks, human capital and TFP in the period under investigation. Results are available upon request.
} 
Therefore, investing in $\mathrm{R} \& \mathrm{D}$ activities is an important way that an industry can increase its productivity. To the extent that technology is appropriate and can flow across industries and countries, intra-industry as well as domestic and international inter-industry spillovers are found to be important channels for an industry to acquire advanced technology and gain in productivity. Competitive forces in the EU and increased trade and integration in markets, perhaps, have facilitated the technology diffusion across industries and countries. EU policy makers should further promote not only higher $\mathrm{R} \& \mathrm{D}$ spending via subsidization and/or tax credits to firms which do R\&D, but also should eliminate policies (e.g., strict product and labor market regulations) that impede technology to spillover.

The major finding, however, of the study relates to the role of human capital. The inclusion of human capital in the model has reduced the size of the R\&D spillover estimates reported in past related studies. Further, its role is found to be both quantitatively and statistically significant for productivity gains. The channel through which human capital influences productivity is by determining the capacity of an economy to innovate new technologies suited to domestic production (Romer 1990), as it accounts for aspects of innovation not captured by the R\&D sector while it also facilitates the realization of R\&D spillovers. Finally, the quality of human capital data is of utmost importance. Clearly, better human capital estimates at the industry (and firm) level could provide more useful insights as to the role of human capital and the possible complementarities between human capital and R\&D in the economic growth process.

Acknowledgments We would like to thank our colleagues in the Utrecht School of Economics, Utrecht University and in the Department of Banking and Financial Management, University of Piraeus as well as two anonymous referees for valuable comments and suggestions. Any remaining caveat is ours.

Open Access This article is distributed under the terms of the Creative Commons Attribution Noncommercial License which permits any noncommercial use, distribution, and reproduction in any medium, provided the original author(s) and source are credited.

\section{Appendix 1: variables, data sources and manufacturing industries}

Annual raw data are retrieved from various sources. A total factor productivity (TFP) index is constructed using the Structural Analysis industrial database (STAN) of the OECD $(2002 \mathrm{a}, \mathrm{b})$, which among other variables provides information at industry-level on value added and investment (to construct physical capital stock using the perpetual inventory method), and the 60-Industry Database of the Groningen Growth and Development Centre (GGDC 2006) to extract data on labor, which for productivity purposes, is measured as average annual hours worked rather than number of employees. Following Keller (2002), TFP is calculated as the difference between output and cost-weighted input growth.

Data on private R\&D expenditures by industry are retrieved from the OECD (2002a, b) Business Enterprise Expenditure on Research and Development (BERD, vol. 2002) database. The domestic industry's cumulative R\&D stocks $\left(S_{i j, t}\right)$ are calculated from the R\&D expenditure series using the perpetual inventory method. 
The international intra-industry R\&D flows are the import-weighted R\&D capital stocks $\left(S_{i j, t}^{f}\right)$ and are constructed by multiplying the industry's cumulative R\&D stocks at foreign country by the bilateral import flows between the foreign and the domestic country (i.e., all R\&D stock performed in the same industry, $j$, in the abroad, which, via import share, flows and impacts on the TFP of the same industry, $j$, in the domestic country). The bilateral import flows are obtained from the OECD (2000) Bilateral Trade Database(BTD): 1980-1998. Therefore, the size of the foreign $R \& D$ acquired from the importing domestic industry depends on the origin of imports and the size of R\&D activities performed there.

We employ the input-output matrix of each one country in our sample to construct the domestic inter-industry R\&D flows, i.e. R\&D flows between the domestic industry and the rest of the domestic industries $\left(S_{i j, t}^{\mathrm{io}}\right)$, and the international interindustry R\&D flows, i.e. R\&D flows between the domestic industry and the rest of the industries at the foreign country $\left(S_{i j, t}^{f, i o}\right)$. The World Bank (2001) Production and Trade Database (PTD): 1976-1999 provides data on both input-output tables for every country and intermediate import share tables that demonstrate the import share of intermediates utilized by each industry in each country.

Country-level data on average years of schooling of the total population aged over 25 are extracted from Barro and Lee $(1993,1996,2001)$ and de la Fuente and Domènech (2006) database (Tables 2, 3, 4).

Table 2 Manufacturing industries

\begin{tabular}{|c|c|c|}
\hline Manufacturing industries & Abbreviation & ISIC code (Rev. 3 ) \\
\hline Food products, beverages and tobacco & FOD & $15-16$ \\
\hline Textiles, textiles products, leather and footwear & TEX & $17-19$ \\
\hline Wood, and products of wood and cork & WOD & 20 \\
\hline Pulp, paper, paper products, printing and publishing & PAP & $21-22$ \\
\hline Coke, refined petroleum products and nuclear fuel & $\mathrm{COK}$ & 23 \\
\hline Chemicals excluding pharmaceuticals & $\mathrm{CHE}$ & 24 less 2423 \\
\hline Pharmaceuticals & PHA & 2423 \\
\hline Rubber and plastics products & RUB & 25 \\
\hline Other non-metallic mineral products & ONM & 26 \\
\hline Iron and steel & IAS & $271+2731$ \\
\hline Non-ferrous metals & NFM & $272+2732$ \\
\hline Fabricated metal products (excluding machinery and equipment) & FAB & 28 \\
\hline Machinery and equipment, n.e.c. & MAC & 29 \\
\hline Office, accounting and computing machinery & OFF & 30 \\
\hline Electrical machinery and apparatus, n.e.c. & ELE & 31 \\
\hline Radio, television and communication equipment & RAD & 32 \\
\hline Medical, precision and optical instruments & MED & 33 \\
\hline Motor vehicles, trailers and semi-trailers & MOT & 34 \\
\hline Building and repairing ships and boats & SHI & 351 \\
\hline Aircraft and spacecraft & AIR & 353 \\
\hline Other manufacturing (furniture; manufacturing n.e.c.; recycling) & OMA & $36+37$ \\
\hline
\end{tabular}




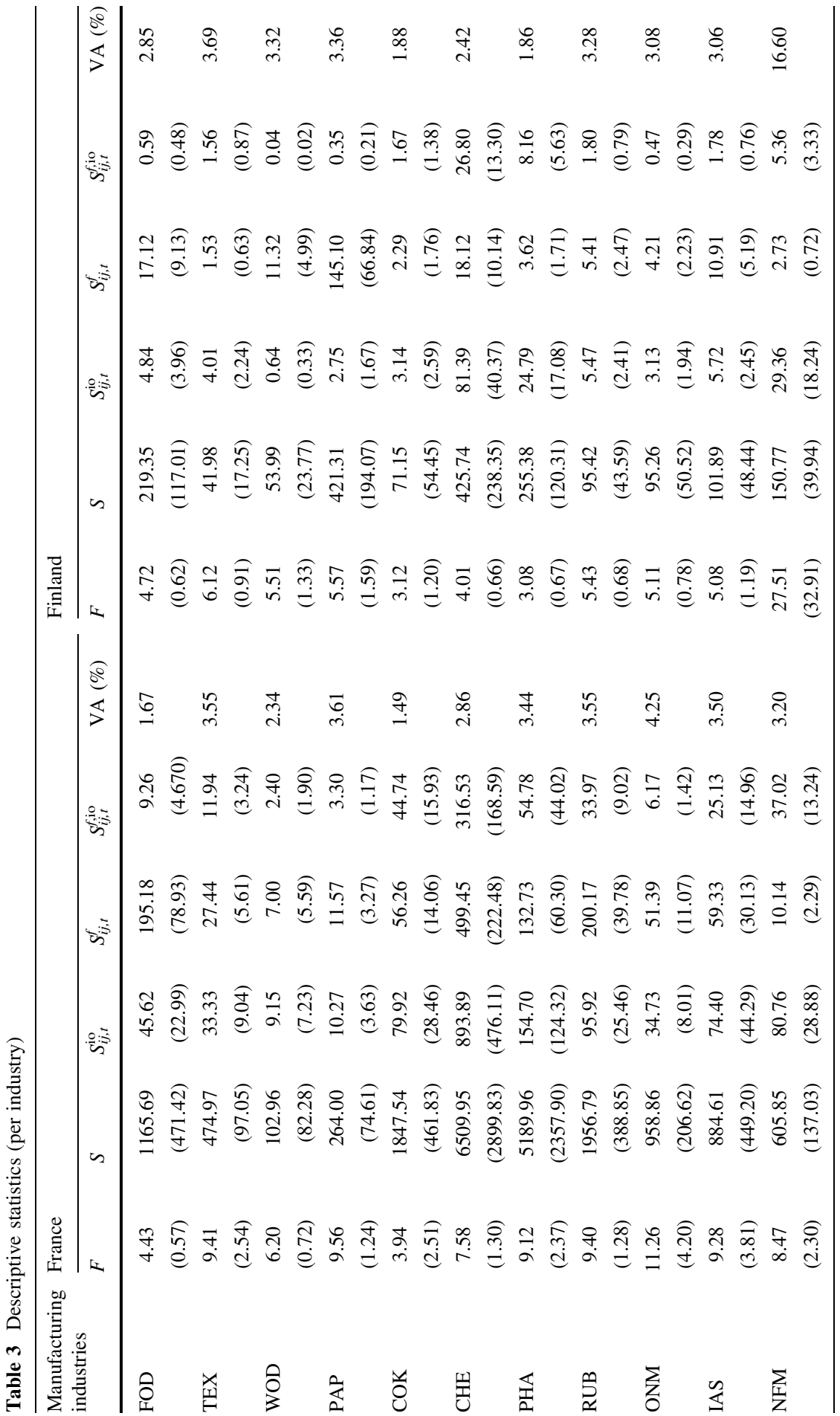

\section{型 Springer}




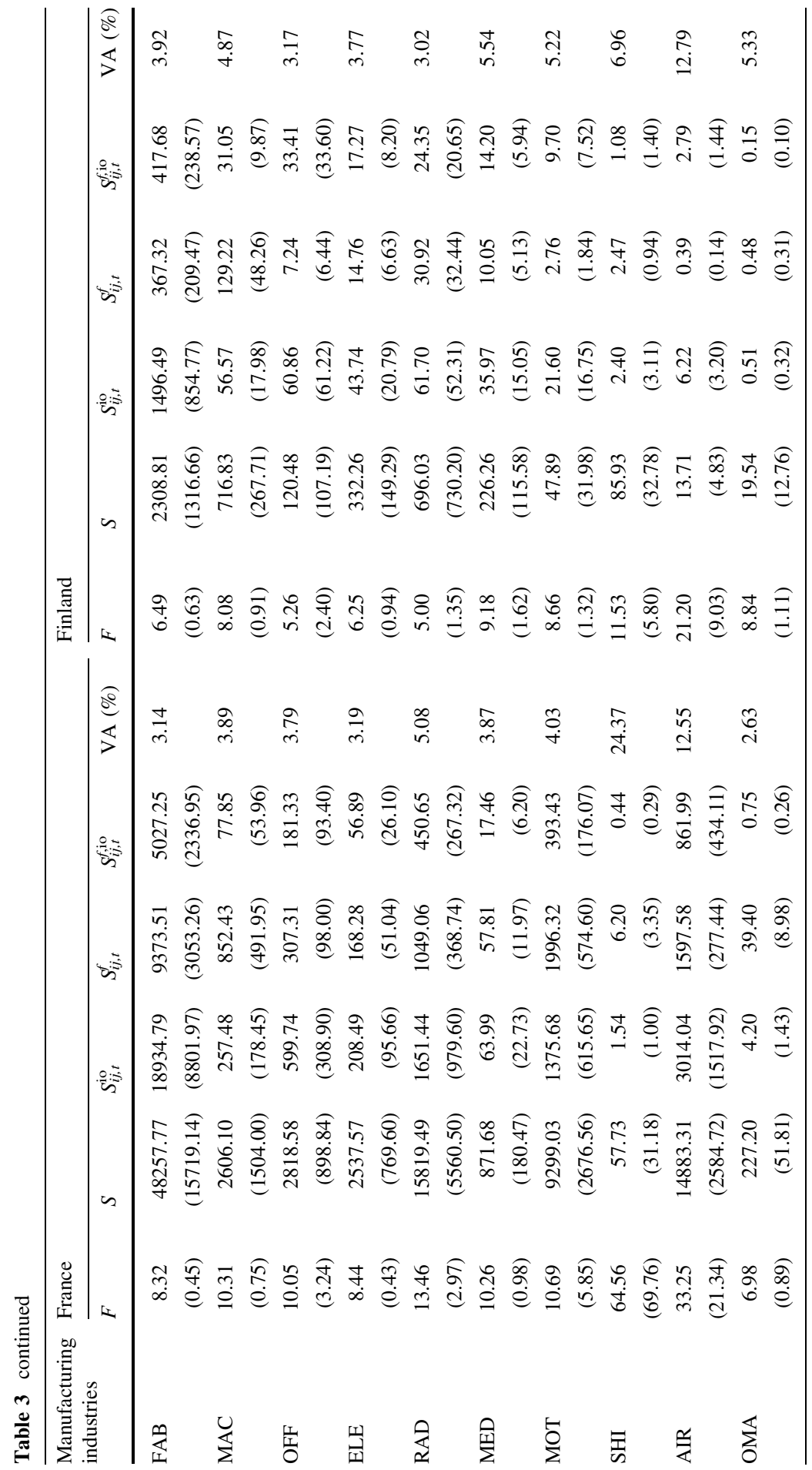




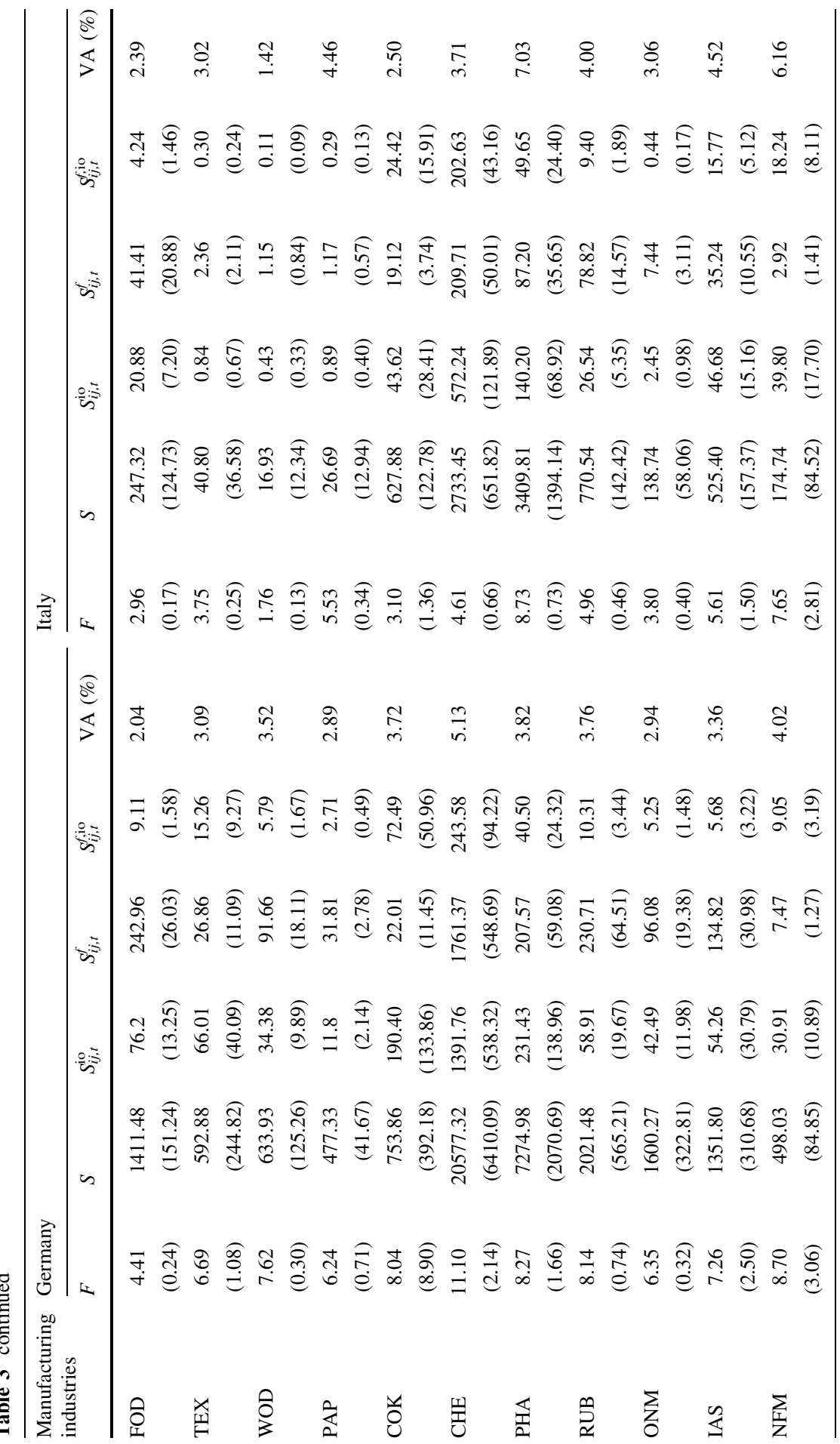

\section{暨 Springer}




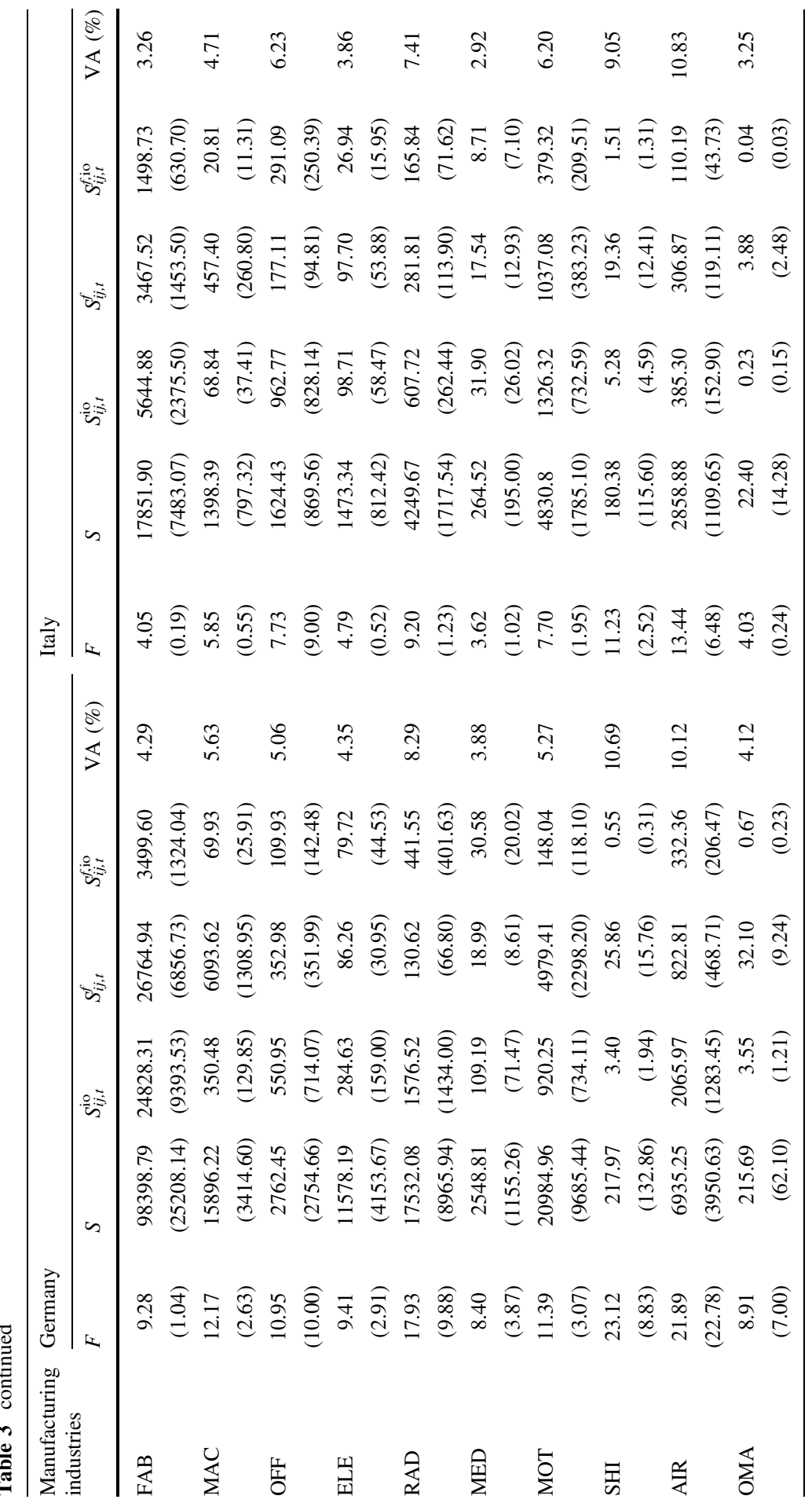




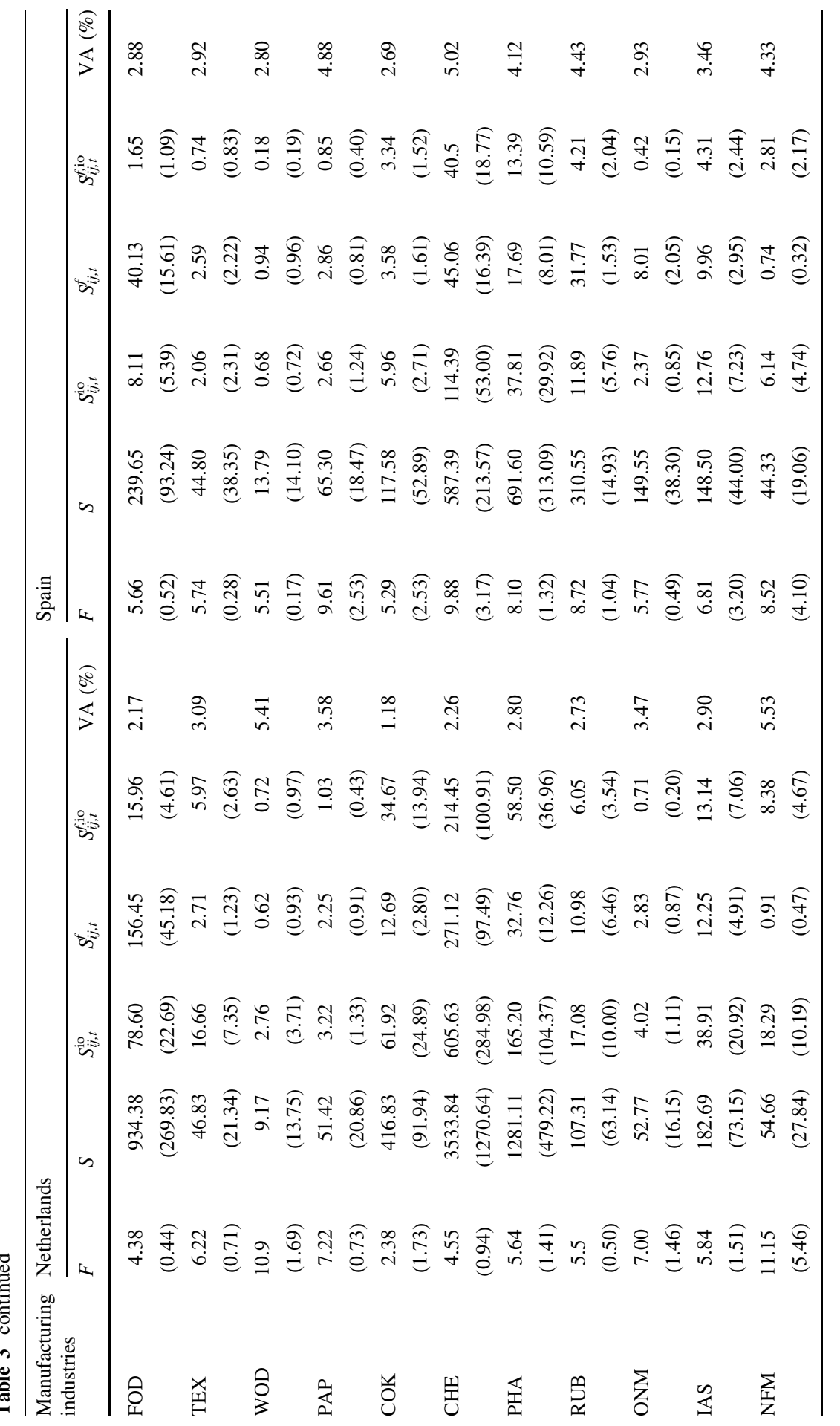

\section{垪 Springer}




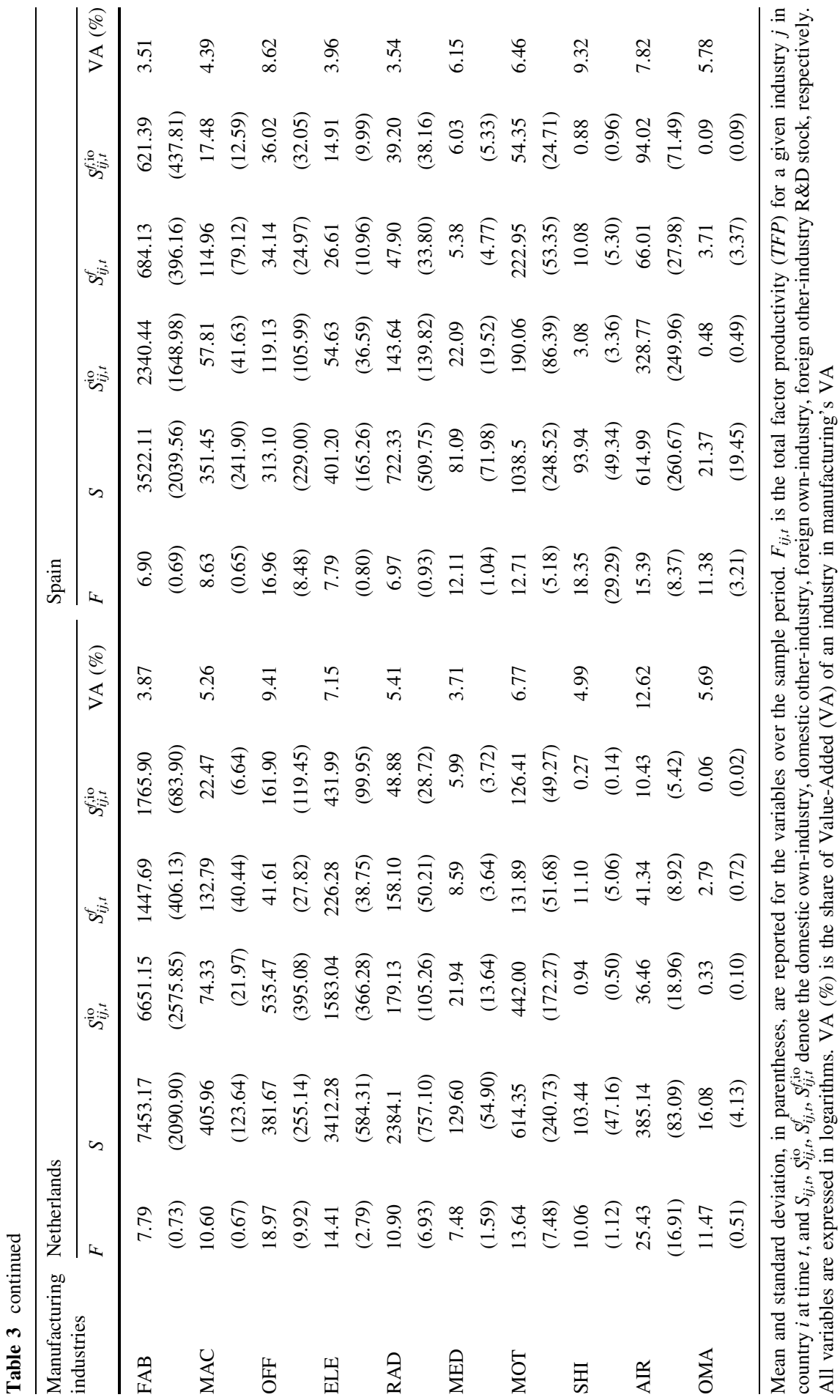


Table 4 Descriptive statistics (human capital)

\begin{tabular}{llr}
\hline Countries & $\mathrm{HC}^{\mathrm{BL}}$ & $\mathrm{HC}^{\mathrm{DD}}$ \\
\hline Finland & $9.16(0.86)$ & $10.80(0.51)$ \\
France & $7.64(0.41)$ & $10.36(0.31)$ \\
Germany & $9.34(0.36)$ & $12.73(0.37)$ \\
Italy & $6.22(0.47)$ & $7.90(0.58)$ \\
Netherlands & $8.66(0.36)$ & $10.76(0.53)$ \\
Spain & $6.10(0.68)$ & $6.92(0.68)$ \\
\hline
\end{tabular}

Mean and standard deviation, in parentheses, are reported for the variables over the sample period. $\mathrm{HC}_{i, t}^{\mathrm{BL}}$ is the Barro and Lee human capital measure while $\mathrm{HC}_{i, t}^{\mathrm{DD}}$ is the de la Fuente and Domènech human capital measure. All variables are expressed in logarithms

\section{Appendix 2: panel-based integration and cointegration analysis}

Table 5 Panel unit root tests

\begin{tabular}{|c|c|c|}
\hline Variables & Without trend & With trend \\
\hline \multicolumn{3}{|l|}{$F_{i j, t}$} \\
\hline Levels & $-1.56(3)$ & $-1.77(2)$ \\
\hline Differences & $-4.69(2)^{*}$ & $-5.68(1)^{*}$ \\
\hline \multicolumn{3}{|l|}{$S_{i j, t}$} \\
\hline Levels & $-1.26(2)$ & $-1.49(2)$ \\
\hline Differences & $-4.33(2)^{*}$ & $-5.28(1)^{*}$ \\
\hline \multicolumn{3}{|l|}{$S_{i j, t}^{\mathrm{io}}$} \\
\hline Levels & $-1.81(2)$ & $-2.02(3)$ \\
\hline Differences & $-4.82(1)^{*}$ & $-5.70(1)^{*}$ \\
\hline \multicolumn{3}{|l|}{$S_{i j, t}^{f}$} \\
\hline Levels & $-1.23(2)$ & $-1.58(2)$ \\
\hline Differences & $-4.53(1)^{*}$ & $-4.64(1)^{*}$ \\
\hline \multicolumn{3}{|l|}{$S_{i j, t}^{f, i o}$} \\
\hline Levels & $-1.17(2)$ & $-1.46(2)$ \\
\hline Differences & $-4.24(1)^{*}$ & $-4.37(1)^{*}$ \\
\hline \multicolumn{3}{|l|}{$\mathrm{HC}_{i, t}^{\mathrm{BL}}$} \\
\hline Levels & $-1.63(2)$ & $-1.76(2)$ \\
\hline Differences & $-4.01(1)^{*}$ & $-4.33(1)^{*}$ \\
\hline \multicolumn{3}{|l|}{$\mathrm{HC}_{i, t}^{\mathrm{DD}}$} \\
\hline Levels & $-1.56(2)$ & $-1.75(2)$ \\
\hline Differences & $-4.35(1)^{*}$ & $-4.63(1)^{*}$ \\
\hline
\end{tabular}

$\overline{F_{i j, t} \text { is the total factor productivity (TFP) for a given industry } j \text { in country } i \text { at time } t \text {, and } S_{i j, t}, S_{i j, t}^{\text {io }}, S_{i j, t}^{f}, S_{i j, t}^{f, i o}}$ denote the domestic own-industry, domestic other-industry, foreign own-industry, foreign other-industry $\mathrm{R} \& \mathrm{D}$ stock, respectively. $\mathrm{HC}_{i, t}^{\mathrm{BL}}$ is the Barro and Lee human capital measure while $\mathrm{HC}_{i, t}^{\mathrm{DD}}$ is the de la Fuente and Domènech human capital measure. All variables are expressed in logarithms. Figures in parentheses denote the number of lags in the augmented term that ensures white-noise residuals. The optimal lag length was determined by the Akaike Information Criterion and Schwarz-Bayes Information Criterion

* Significant at $1 \%$ 
Table 6 Panel cointegration tests

\begin{tabular}{lllllll}
\hline Panel v-stat & Panel $\rho$-stat & Panel pp-stat & Panel adf-stat & Group $\rho$-stat & Group pp-stat & Group adf-stat \\
\hline$-6.521^{*}$ & $-4.720^{*}$ & $-5.756^{*}$ & $-6.005^{*}$ & $-4.081^{*}$ & $-5.584^{*}$ & $-6.063^{*}$ \\
\hline
\end{tabular}

Pedroni (1999) panel-based cointegration tests for Eq. (1), where human capital $\left(\mathrm{HC}_{i, t}\right)$ isHC ${ }_{i, t}^{\mathrm{DD}}$

* Significant at $1 \%$

\section{References}

Aghion P, Howitt P (1998) Endogenous growth theory. MIT Press, Cambridge

Apergis N, Economidou C, Filippidis I (2008) Innovation, technology transfer and labor productivity linkages: evidence from a panel of manufacturing industries. Tjalling Koopmans Institute (TKI) Discussion Papers Series nr. 08-29, Utrecht School of Economics, Utrecht University/Review of World Economics (Weltwirtschaftliches Archiv) (forthcoming)

Ashenfelter O, Harmon C, Oosterbeek H (1999) A review of estimates of the schooling/earnings relationship, with tests for publication bias. Lab Econ 6:453-470

Badinger H, Egger P (2008) Intra- and inter-industry productivity spillovers in OECD manufacturing: a spatial econometric perspective, CESifo Working Paper, No. 2181

Baltagi BH (2005) Econometric analysis of panel data, 3rd edn. Wiley, New York

Barro R, Lee JW (1993) International comparisons of educational attainment. J Monetary Econ 32: 363-394

Barro R, Lee JW (1996) International measures of schooling years and schooling quality. Am Econ Rev $86: 218-223$

Barro R, Lee JW (2000) International data on educational attainment: updates and implications. NBER Working Paper No. 7911, National Bureau of Economic Research

Barro R, Lee JW (2001) International data on educational attainment: updates and implications. Oxf Econ Pap 53:541-563

Barro R, Sala-i-Martin X (1995) Economic growth. MIT Press, Cambridge

Bassanini A, Scarpetta S (2001) Does human capital matter for growth in the OECD countries? Evidence from pooled mean-group estimates. Working Paper 282, Economics Department, OECD

Benhabib J, Spiegel M (1994) The role of human capital in economic development: evidence from aggregate cross-country date. J Monetary Econ 34:143-173

Cameron G, Proudman J, Redding S (2005) Technological convergence, R\&D, trade and productivity growth. Eur Econ Rev 49:775-807

Chen B, McCoskey S, Kao C (1999) Estimation and inference of a cointegrated regression in panel data: a Monte Carlo study. Am J Math Manag Sci 19:75-114

Coe DT, Helpman E (1995) International R\&D spillovers. Eur Econ Rev 39:859-887

Coe DT, Helpman E, Hoffmaister AW (1997) North-South R\&D spillovers. Econ J 107:134-149

Coe DT, Helpman E, Hoffmaister AW (2008) International R\&D spillovers and institutions. IMF Working Paper No. 08/104

De la Fuente A, Doménech R (2000) Human capital in growth regressions: how much difference does data quality make? Working Paper 262, Economics Department, OECD

De la Fuente A, Doménech R (2006) Human capital in growth regressions: how much difference does data quality make? J Eur Econ Assoc 4:1-36

Del Barrio-Castro T, Lopez-Bazo E, Serrano-Domingo G (2002) New evidence on international R\&D spillovers, human capital and productivity in the OECD. Econ Lett 77:41-45

Engelbrecht HJ (1997) International R\&D spillovers, human capital and productivity in OECD economies: an empirical investigation. Eur Econ Rev 41:1479-1488

Engelbrecht HJ (2002) Human capital and international knowledge spillovers in TFP growth of a sample of developing countries: an exploration of alternative approaches. Appl Econ 34:831-841

Engelbrecht HJ (2003) Human capital and economic growth: cross-section evidence for OECD countries. Econ Rec 79:S40-S51

Fagerberg J, Verspagen B (1999) Productivity, R\&D spillovers and trade. Working Papers 3, Centre for Technology, Innovation and Culture, University of Oslo 
Falvey R, Foster N, Greenaway D (2004) Imports, exports, knowledge spillovers and growth. Econ Lett 85:209-213

Frantzen D (2000) R\&D, human capital and international technology spillovers: a cross-country analysis. Scand J Econ 102:57-75

Frantzen D (2002) Intersectoral and international R\&D knowledge spillovers and total factor productivity. Scot J Polit Economy 49:280-303

Funk M (2001) Trade and international R\&D spillovers among OECD countries. Southern Econ J 67:725-736

GGDC (2006) 60-Industry database. Groningen growth and development centre, Groningen. Available via GGDC. http://www.ggdc.nl

Guellec D, Pottelsberghe Van, de la Potterie B (2004) From R\&D to productivity growth: do the institutional settings and the source of funds of R\&D matter? Oxf Bull Econ Stat 66:353-378

Griffith R, Redding S, Van Reenen J (2004) Mapping the two faces of R\&D: productivity growth in a panel of OECD industries. Rev Econ Stat 86:883-895

Grossman G, Helpman E (1991) Innovation and growth in the global economy. MIT Press, Cambridge

Im K, Pesaran H, Shin Y (2003) Testing for unit roots in heterogeneous panels. J Econometr 115:53-74

Islam N (1995) Growth empirics: a panel data approach. Q J Econ 110:1127-1170

Kao C, Chiang M-H (2000) On the estimation and inference of a cointegrated regression in panel data. Adv Econom 15:179-222

Kao C, Chiang MH, Chen B (1999) International R\&D spillovers: an application of estimation and inference in panel cointegration. Oxf Bull Econ Stat 61:691-709

Keller W (2002) Trade and the transmission of technology. J Econ Growth 7:5-24

Lee G (2006) The effectiveness of international knowledge spillover channels. Eur Econ Rev 50:20752088

Lichtenberg FR, Pottelsberghe Van, de la Potterie B (1998) International R\&D spillovers: a comment. Eur Econ Rev 42:1483-1491

Lucas R Jr (1988) On the mechanisms of economic development. J Monetary Econ 22:3-42

Lucas R Jr (1990) Why doesn't capital flow from rich to poor countries? Am Econ Rev 80:92-96

Luintel KB, Khan M (2004) Are International R\&D spillovers costly for the United States? Rev Econ Stat 86:896-910

Mankiw GN, Romer D, Weil DN (1992) A contribution to the empirics of economic growth. Q J Econ 107:407-437

Nelson R, Phelps E (1966) Investment in humans, technological diffusion, and economic growth. Am Econ Rev 5:69-75

OECD (2000) Bilateral trade database (BTD): 1980-1998 CD-ROM. Organization for Economic Cooperation and Development, Paris

OECD (2002a) Industry structural analysis database (STAN) CD-ROM. Organization for Economic Cooperation and Development, Paris

OECD (2002b) Business enterprise expenditure on research and development (BERD) CD-ROM. Organization for Economic Cooperation and Development, Paris

Park S (2004) International and intersectoral R\&D spillovers in the OECD and East Asian economies. Econ Inquiry 42:739-757

Pedroni P (1999) Critical values for cointegration tests in heterogeneous panels with multiple regressors. Oxf Bull Econ Stat 61:653-670

Pedroni P (2000) Fully modified OLS for heterogeneous cointegrated panels. Adv Econom 15:93-130

Pritchett L (1996) Measuring outward orientation in LDCs: can it be done? J Dev Econ 49:307-335

Redding S (1996) The low-skill, low-quality trap: strategic complementarities between human capital and R\&D. Econ J 106:458-470

Rivera-Batiz LA, Romer P (1991) Economic integration and economic growth. Q J Econ 106:531-556

Romer P (1990) Human capital and growth: theory and evidence. In: Meltzer A (ed) Unit roots, investment measures and other essays. Carnegie-Rochester Conference Series on Public Policy 32, pp 251-286

Scarpetta S, Tressel T (2002) Productivity and convergence in a panel of OECD industries: do regulations and institutions matter? OECD Working Paper No. 342. Organization for Economic Co-operation and Development, Paris

Stock JH (1987) Asymptotic properties of least squares estimations of cointegrating vectors. Econometrica 55:1035-1056

Temple J (1999) A positive effect of human capital on growth. Eon Lett 65:131-134 
Van Pottelsberghe De La Potterie B, Lichtenberg F (2001) Does foreign direct investment transfer technology across borders? Rev Econ Stat 83:490-497

Westerlund J (2006) Testing for panel cointegration with multiple structural breaks. Oxf Bull Econ Stat 68:101-132

World Bank (2001) Production and trade database (PTD): 1976-1999 CD-ROM. World Bank, Washington 